\section{Repair of Bone Defects with Chitosan- Collagen Biomembrane and Scaffold Containing Calcium Aluminate Cement}

Paola Castro de Moraes ${ }^{1}$, Isabela Cristina de Souza Marques², Fernanda Gonçalves Basso ${ }^{3}$, Hebert Luis Rossetto ${ }^{4}$, Fernanda de Carvalho Panzeri Piresde-Souza ${ }^{5}$, Carlos Alberto de Souza Costa $^{3}$, Lucas da Fonseca Roberti Garcia ${ }^{6}$

Innovative biomaterials can provide a promising new direction for the treatment of bone defects, stimulating a proper repair process, with no damage to adjacent tissues. The purpose of this in vivo study was to evaluate the biocompatibility and the osteoinductive capacity of chitosan-collagen biomembrane and scaffold containing calcium aluminate cement. Eighteen New Zealand white rabbits (Oryctolagus cuniculus) were distributed according to the experimental times of analysis $(7,15$ and 30 days). Four bone defects were created in the rabbits calvaria, which were individually filled with the biomembrane, scaffold, blood clot (negative control) and autologous bone (positive control). Histopathological analysis was performed using optical microscope at $32 \times, 64 x, 125 \times$ and $320 x$ magnifications. Cell response to inflammation and new bone tissue formation was quantified using a score system. The biomembrane group presented greater inflammatory response at 15 days, with significant difference to autologous bone group $(p<0.05)$. There was no statistically significant difference for foreign body type reaction among groups ( $p>0.05)$. Concerning new bone formation, linear closure of the defect area was observed more evidently in the group with autologous bone. The scaffold group presented similar results compared with the autologous bone group at 30 days ( $>0.05)$. Both tested biomaterials presented similar biocompatibility compared with the control groups. In addition, the biomembrane and scaffold presented similar osteoinductive capacity, stimulating bone repair process in the course of the experimental time intervals.

\author{
'Department of Clinics and \\ Surgery, Jaboticabal School of \\ Agricultural and Veterinary Sciences, \\ UNESP - Universidade Estadual \\ Paulista, Jaboticabal, SP, Brazil \\ ${ }^{2}$ Department of Pathology, Ribeirão \\ Preto School of Medicine, USP \\ - Universidade de São Paulo, \\ Ribeirão Preto, SP, Brazil \\ ${ }^{3}$ Department of Physiology and \\ Pathology, Araraquara Dental School, \\ UNESP - Universidade Estadual \\ Paulista, Araraquara, SP, Brazil \\ ${ }^{4}$ Binderware Biomaterials Ltda., \\ São Carlos, SP, Brazil \\ ${ }^{5}$ Department of Dental Materials and \\ Prosthodontics, Ribeirão Preto Dental \\ School, USP - Universidade de São \\ Paulo, Ribeirão Preto, SP, Brazil. \\ ${ }^{6}$ Department of Dentistry - \\ Endodontics Division, Health Sciences \\ Center, UFSC - Universidade Federal de \\ Santa Catarina, Florianópolis, SC, Brazil
}

Correspondence: Lucas da Fonseca Roberti Garcia, Avenida Madre Benvenuta, 388, apt. 713, Bairro Trindade, 88036-500 Florianópolis, SC, Brasil. Tel: +55-48-3721-5843. e-mail: drlucas.garcia@gmail.com

Key Words: biocompatible materials, bone regeneration, inflammation, calcium aluminate cement

\section{Introduction}

Bone defects generally require reconstruction of the affected area (1). Nowadays, the main therapies consist in grafts of bone tissue from different origins, which may be homologous, heterologous or autologous (2).

Different biomaterials are used for stimulating bone repair, attaining satisfactory results (3). These biomaterials must not only fill the space previously occupied by bone tissue, but also promote a specific biologic response (4). Membranes prevent proliferation of non-osteogenic cells in the defect, whereas scaffolds are used to provide support for slower bone cells to form a quality substitute tissue (4).

Collagen is one of the most used biomaterials for this purpose, due to its biocompatibility and bioactivity (4). The collagen matrix stimulates cellular migration, proliferation and infiltration, considered important properties for regenerative process (5). However, its rapid biodegradation has been reported as the main disadvantage when it is used alone (6).

The association between collagen and chitosan has been currently one of the most studied (7-9). Chitosan is obtained by the reaction of deacetylation of chitin in an alkaline medium (3). Chitin is a natural polymer with a highly organized crystalline structure, making it practically insoluble in most organic solvents (10). In addition, chitin has low chemical reactivity and provides adequate mechanical resistance to the compound formed by association with collagen (10).

The interaction of these biomaterials with minerals has been widely reported $(3,7,8,11)$. Chitosan in association with hydroxyapatite was shown to maximize the in vivo osteogenic capacity, allowing internal growth of the compound with accelerated resorption of the matrix (9). Calcium aluminate has also been pointed out in the last few years as a promising material for bone regeneration, mainly due to the intense release of $\mathrm{Ca}^{2+}$ ions and neutral $\mathrm{pH}$ produced in the medium (12). In addition, trivalent inorganic ions, like $\mathrm{Al}^{3+}$, increase $\mathrm{Fgf}-2$ expression, which plays a relevant role in osteogenesis and cementogenesis (13). However, Demirkaya et al. (14) reported increase of Al levels in plasma and liver after treatment with hydraulic calcium silicate cements. Furthermore, calcium aluminate is able to promote strong increase in the mechanical strength of the biomaterial, which is an indispensable requisite for scaffolds (15). 
Thus, a scaffold and a biomembrane composed by collagen and chitosan, containing calcium aluminate cement as mineral phase, is believed to form a biomaterial able to provide adequate support for bone repair (11). This in vivo study evaluated the biocompatibility and osteoinductive capacity of these new experimental biomaterials as a biomembrane and a scaffold. The null hypothesis tested was that the tissue response caused by these biomaterials would be similar among them and the control groups.

\section{Material and Methods}

\section{Selection of Animals}

The present study was conducted in compliance with the ethical principles adopted by the National Council of Control of Animal Experimentation, and prior approval of the Ethics Committee on the Use of Animals (Process CEUA No. 12.1.1059.53.3).

Sample size was estimated to establish an adequate number of specimens required to detect significant difference of 5\% among experimental and control groups. Based on this data, 18 New Zealand white rabbits (Oryctolagus cuniculus) were randomly distributed into three groups of six animals each, with reference to the post-operative evaluation time intervals of 7, 15 and 30 days. The animals were kept in individual cages $\left(2400 \mathrm{~cm}^{2}\right)$ and fed with potable water and appropriate rations ad libitum throughout the whole experiment.

\section{Tested Biomaterials}

The experimental biomembrane and scaffold tested in this study (Fig. 1) were prepared by an association of collagen and chitosan, with calcium aluminate as mineral phase. The main components and biomaterials were prepared as follows:

Collagen preparation: $20 \mathrm{~g}$ of bovine tendon were washed with deionized water to remove excess flesh, blood and fat, and shredded. Next, the obtained fibers were soaked in $500 \mathrm{~mL}$ of a $0.9 \%$ sodium chloride solution $(\mathrm{m} / \mathrm{V})$ at 20 ${ }^{\circ} \mathrm{C}$ for $20 \mathrm{~h}$, without stirring. Then, the fibers were filtered, washed in deionized water and soaked in a salt solution

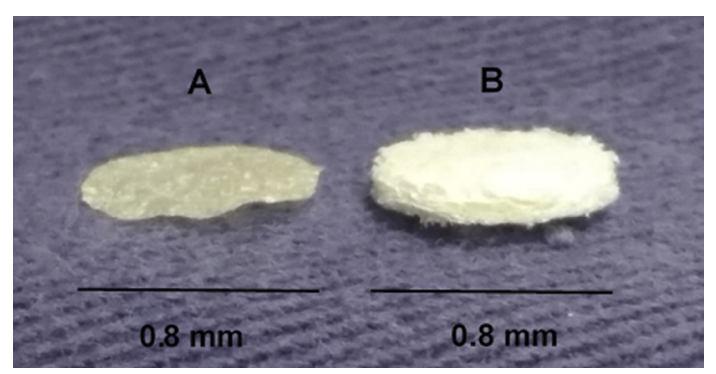

Figure 1. Biomaterials evaluated. Biomembrane (A) and Scaffold (B). (either sodium chloride or sulphate, $1.42 \mathrm{M}$; potassium, $0.37 \mathrm{M}$; and calcium, $0.54 \mathrm{M})$ with $6 \%(\mathrm{~m} / \mathrm{V})$ dimethyl sulfoxide (DMSO) at $20{ }^{\circ} \mathrm{C}$ for $32 \mathrm{~h}$, stirred occasionally. This process was repeated for $4 \mathrm{~h}$ with constant stirring, followed by $4 \mathrm{~h}$ without stirring, at $20{ }^{\circ} \mathrm{C}$. The resulting suspension was filtered and the solid material was soaked in $500 \mathrm{~mL}$ of $3 \%$ boric acid solution $(\mathrm{m} / \mathrm{V})$ at $20{ }^{\circ} \mathrm{C}$ for 12 $\mathrm{h}$, rinsed with a copious amount of deionized water and finally suspended in $280 \mathrm{~mL}$ of acetic acid $(0.55 \mathrm{~mol} / \mathrm{L}, \mathrm{pH}$ $3.5)$ to obtain a collagen gel at $1.1 \%(\mathrm{~m} / \mathrm{V})$ concentration.

Chitosan preparation: $1 \mathrm{~g}$ of chitosan was diluted in $50 \mathrm{~mL}$ of $2 \%$ acetic acid $(\mathrm{m} / \mathrm{V})$, in a hot plate stirrer; the resulting solution was placed in a hermetically closed receptacle and stored at $5{ }^{\circ} \mathrm{C}$.

Calcium aluminate preparation: calcium aluminate phases were conveniently synthesized by reacting calcined alumina (Alcoa World Alumina Brasil Ltda, Belém, PA, Brazil; 98.8 wt $\% \mathrm{Al}_{2} \mathrm{O}_{3}$ ) with calcium oxide (Labsynth Produtos para Laboratórios Ltda, Diadema, SP, Brazil; $\mathrm{CaO}$ P.A.), according to their phase diagram, as follows: calcium monoaluminate $\left(\mathrm{CaO} \cdot \mathrm{Al}_{2} \mathrm{O}_{3}\right)$ at $1300{ }^{\circ} \mathrm{C}$ for $1 \mathrm{~h}$; monocalcium dialuminate $\left(\mathrm{CaO} .2 \mathrm{Al}_{2} \mathrm{O}_{3}\right)$ at $1450{ }^{\circ} \mathrm{C}$ for $1 \mathrm{~h}$; tricalcium aluminate $\left(\mathrm{CaO} .3 \mathrm{Al}_{2} \mathrm{O}_{3}\right)$ at $1300{ }^{\circ} \mathrm{C} \times 1 \mathrm{~h}$, dodecalcium hepta-aluminate $\left(12 \mathrm{CaO} 7 \mathrm{Al}_{2} \mathrm{O}_{3}\right)$ at $1300{ }^{\circ} \mathrm{C}$ for 1 hour. These phases, named by the abbreviations: $C A$, CA2, C3A and C12A7, respectively, are usually components of most commercial calcium aluminate cements, with importance given by their order of appearance. Where the cement itself is concerned, additions are made to enhance its performance as a biomaterial, like for example, dispersants (0.4-0.8\%), plasticizers (2-4\%), setting agents (up to 1\%) and radiopacifiers (20-35\%), all percentages in relation to cement weight. EndoBinder (Binderware, São Carlos, SP, Brazil) has accomplished this aim and it was, therefore, used in this study as the appropriate calcium aluminate cement. The EndoBinder powder is mainly composed (wt\%) of $\mathrm{Al}_{2} \mathrm{O}_{3}(68.0)$, $\mathrm{CaO}(31.0), \mathrm{SiO}_{2}(0.3-0.8)$, $\mathrm{MgO}(0.4-0.5)$ and $\mathrm{Fe}_{2} \mathrm{O}_{3}(0.3)$. The surface morphology and the presence of calcium-aluminate phases in the cement was described by Soares et al. (11).

Scaffold preparation: $12 \mathrm{~g}$ collagen gel and $6 \mathrm{~g}$ chitosan were gradually added to $0.2 \mathrm{~g}$ of calcium aluminate cement, under stirring. After cement setting (about $15 \mathrm{~min}$ ), the resulting material was transferred to a plastic receptacle in which it was de-aired in a desiccator associated to a vacuum pump. This material was frozen at $-30{ }^{\circ} \mathrm{C}$ for 12 $h$, and lyophilized to remove water entrapped in the gel without reducing the volume. Scaffolds were gamma-ray sterilized at $20 \mathrm{kGy}$ before use in this study.

Biomembrane preparation: The same initial step as that for scaffold preparation was used, except that the cement was replaced by monocalcium dialuminate (CA2) only. The 
membrane, intended to be a barrier to cell proliferation, was compacted by cold uniaxial pressing $(500 \mathrm{KPa})$ after the de-airing step to its final thickness (instead of being lyophilized), and then dried by an air flow on both surfaces. The biomembrane was also gamma-ray sterilized at $20 \mathrm{kGy}$ before use in this study.

\section{Surgical Procedure}

Forty minutes before the surgical procedure, the animals were treated with prophylactic antibiotic therapy based on ampicillin sodium (40.000 UI/Kg) (Pentabiótico Veterinário Pequeno Porte, Zoetis, Campinas, SP, Brazil). As preanesthesia medication, the animals received acepromazine (Acepran 0.2\%, Vetnil, Louveira, SP, Brazil) and tramadol (Tramadon-Cristália, Itapira, SP, Brazil) at the doses of $1 \mathrm{mg} / \mathrm{kg} \mathrm{IM}$ and $4 \mathrm{mg} / \mathrm{kg} \mathrm{IM}$, respectively. After $10 \mathrm{~min}$, anesthetic induction was performed with the association of ketamine hydrochloride (Ketamina Agener, União Química Farmacêutica Nacional S/A, Embu-Guaçu, SP, Brazil) at the dose of $35 \mathrm{mg} / \mathrm{kg}$ and xylazine hydrochloride (Dopazer, Laboratorios Calier S.A, Barcelona, Spain) at the dose of $5 \mathrm{mg} /$ $\mathrm{kg}$, diluted in the same syringe, via intramuscular injection.

Four bone defects, with a $8 \mathrm{~mm}$ diameter each, were mechanically created in rabbits calvaria by a trephine bur 8 $\mathrm{mm}$ diameter (Neodent, Curitiba, PR, Brazil), under copious cooling with sterile $0.9 \%$ sodium chloride solution. The bone defects on the right side were filled with the scaffold (superior) and membrane (inferior). The bone removed from the defect correspondent to the negative control (blood clot) situated on the left side, inferior portion, was used as filling for the bone defect corresponding to the positive control (autologous graft) left side, superior portion (Fig. 2).

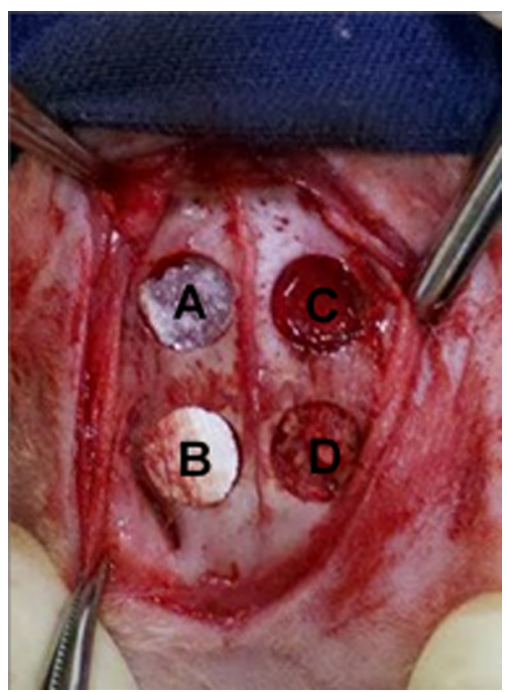

Figure 2. Bone defects created in rabbit calvaria. Biomembrane (A), Scaffold (B), Blood clot (negative control) (C) and Autologous bone (positive control) (D).
At the end of each experimental time interval $(7,15$ and 30 days), the animals were sacrificed by sedation with acepromazine (Acepran 0.2\%, Vetnil) and tramadol (Tramadon-Cristália) at the doses of $1 \mathrm{mg} / \mathrm{kg}$ IM and $4 \mathrm{mg} /$ $\mathrm{kg} I \mathrm{M}$, respectively; followed by anesthetic overdose with thiopental (Pentothal Sodium, Intervet, São Paulo, SP, Brazil).

The portions of the calvaria containing the area in which the bone defects were created were dissected and fixed in 10\% formalin for $48 \mathrm{~h}$. Afterwards, they were washed and decalcified in Morse solution (equal parts of $50 \%$ formic acid and 20\% sodium citrate) for 90 days, at room temperature under agitation, changed after 15 days, totaling six samples of each group per time interval $(n=6)$.

After decalcification, the fragments were dehydrated in ethanol, diaphanized in xylol, and embedded in paraffin, sectioned into semi-serial $5 \mu \mathrm{m}$ sections; 10 sections were discarded and 5 stained with Hematoxylin and Eosin (Merck, Darmstadt, Germany).

\section{Histopathological Analysis}

Analysis of the histopathological events in the bone tissue in the different experimental times was performed in a blind manner, by a single calibrated examiner, using an optical microscope Axio Star Plus (Carl Zeiss, Oberköchen, Germany) at 32x, 64x, 125x and 320x magnifications. The cellular response to inflammation (Table 1) was determined by counting inflammatory cells (lymphocytes, macrophages, granulocytes and plasmocytes) in the area of analysis, in accordance with the criteria of Noetzel et al. (16) and Panzarini et al. (17). The new bone tissue formation (Table 2) in the mechanically created defect was categorized according to the criteria of Moretton et al. (18). The reaction to the foreign body presence (inflammatory giant cells close to the tested biomaterials) was characterized according to the criteria of Sahiri et al. (19), as follows: score 0 - absence of inflammatory giant cells; and score 1 - presence of inflammatory giant cells close to the tested biomaterials.

\section{Statistical Analysis}

The values obtained in the different analyses and different experimental times were statistically compared (2-way ANOVA, Bonferroni test; $p<0.05$ ) after verifying sample normality (Levene test; $p<0.05$ ), with the OriginPro 8 SRO program (OriginLab Corp., Northampton, MA, USA).

\section{Results}

Histopathological Analysis

Representative images of the main histopathological findings may be observed in Figures 3-5.

\section{Biomembrane}

In the initial period (7 days) was noted newly formed 
bone tissue of discrete amplitude, composed of bone trabeculae fragments arranged along the experimental defect. In addition, the presence of moderate inflammatory infiltrate was observed adjacent to the area of the defect, formed by lymphocytes, granulocytes, plasmocytes and some macrophages phagocyting dispersed residues of the tested biomembrane. Osteogenic cells and young blood

Table 1. Score system used to quantify cellular response to inflammation

\begin{tabular}{lc}
\hline $\begin{array}{l}\text { Cellular response } \\
\text { to inflammation }\end{array}$ & Characterization \\
\hline Score 0 & $\begin{array}{c}\text { Absence of inflammatory cells } \\
\text { at the site of analysis. }\end{array}$ \\
Score 1 & $\begin{array}{c}\text { Discrete inflammation: }<25 \text { inflammatory } \\
\text { cells present in the area of analysis. } \\
\text { Moderate inflammation: between } \\
\text { 25-50 inflammatory cells present } \\
\text { in the area of analysis. } \\
\text { Score } 2\end{array}$ \\
& $\begin{array}{c}\text { Severe inflammation }- \text { between } \\
\text { 51-75 inflammatory cells present } \\
\text { in the area of analysis. }\end{array}$ \\
& Formation of abscess: $>75$ inflammatory \\
cells present in the area of analysis.
\end{tabular}
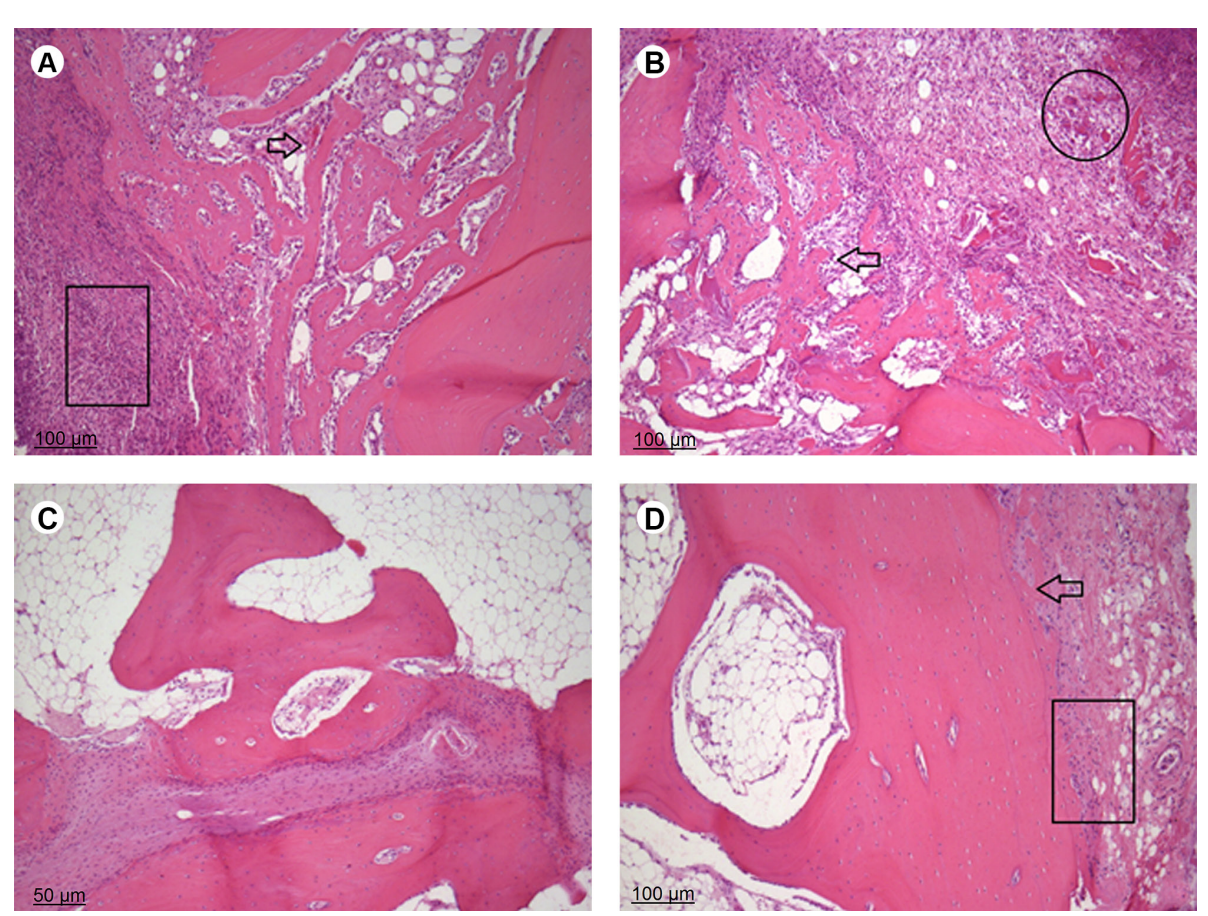

Table 2. Score system used to quantify new bone tissue formation

\begin{tabular}{lc}
\hline $\begin{array}{l}\text { Newly formed } \\
\text { bone tissue }\end{array}$ & Characterization \\
\hline Score 0 & $\begin{array}{c}\text { Absence of new bone tissue formation } \\
\text { Discrete: Presence of small bone trabeculae, } \\
\text { covering less than 25\% of the bone defect area. }\end{array}$ \\
Score 1 & $\begin{array}{c}\text { Moderate: New bone tissue formed, } \\
\text { covering at least 50\% of the defect area. }\end{array}$ \\
Score 2 & $\begin{array}{c}\text { Extensive - Complete coverage of the bone } \\
\text { defect area, with the formation of a bony } \\
\text { bridge around the biomaterial tested. }\end{array}$ \\
\hline
\end{tabular}

cells were present in the site, which characterized a tissue in the repair process. Some giant cells were observed adjacent to the bone defect (Fig. 3A). In general, at 15 days the inflammatory infiltrate still presented moderate amplitude (Fig. 4A). However, in some samples it was possible to observe a severe inflammatory condition associated with intense local macrophagic activity (Fig. 4B). Newly formed bone tissue was shown with a large number of osteogenic cells providing continuity to process the linear closure of experimental defect (Fig. 4A). At 30 days, a persistent inflammatory process of moderate amplitude

Figure 3. (7 days) Biomembrane (A): Immature newly formed bone tissue of discrete amplitude, with thin fragments, composed of bone trabeculae arranged along the mechanically created experimental defect (arrow). Note the presence of moderate inflammatory infiltrate adjacent to the area of the defect, predominantly formed by polymorphous and mononuclear cells (delimitation). H/E, 32×. Scaffold (B): New bone formation in tissue with bone trabeculae projected into the experimental defect (arrow). Observe the presence of numerous capillaries (circle). H/E, 32×. Blood Clot (C): Presence of a discrete inflammatory component and formation of bone tissue with thicker bone trabeculae. H/E, 64×. Autologous bone (D): Linear closure of space between grafted bone and defect margin (arrow), with mineralized tissue formation with morphology similar to that of adjacent bone tissue. Also note the presence of an inflammatory infiltrate of moderate amplitude (delimitation) $\mathrm{H} / \mathrm{E}$, 32×. 

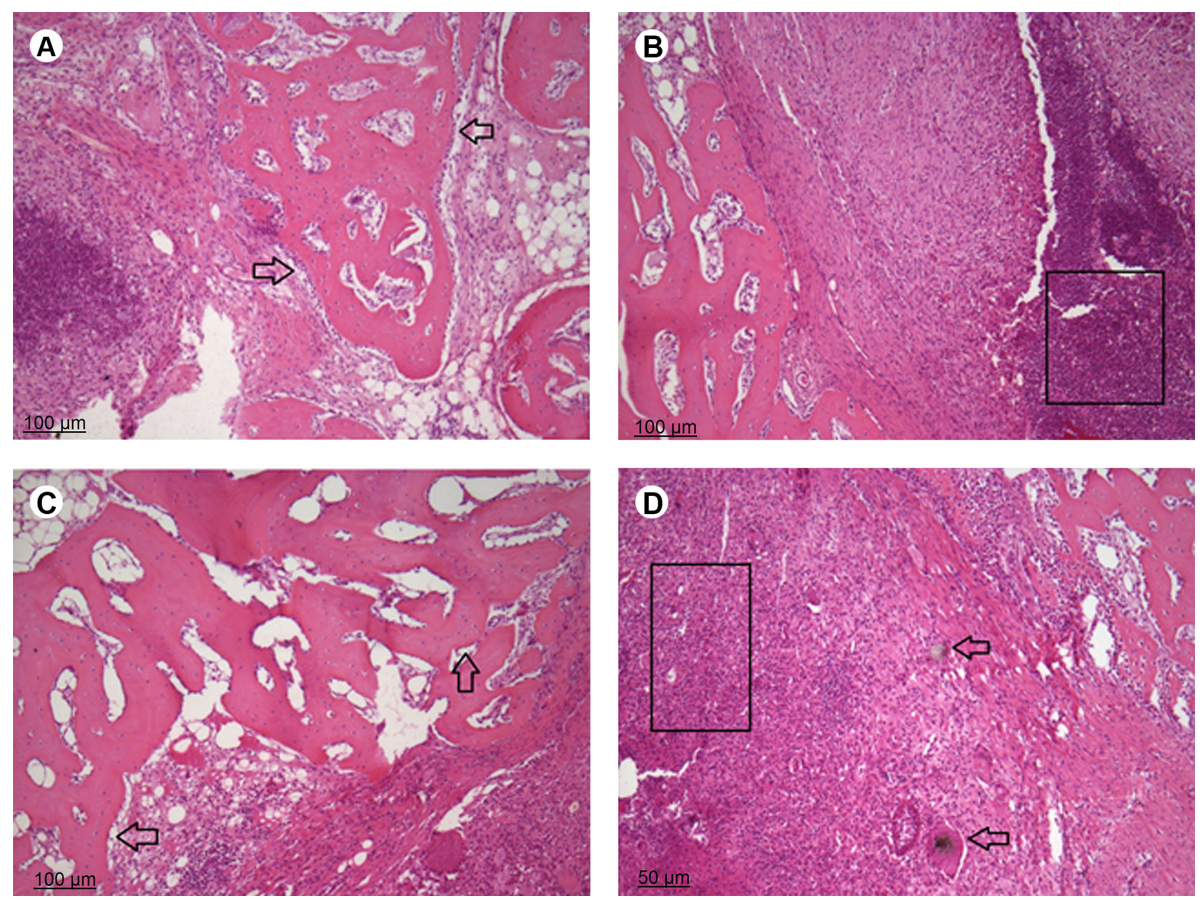

Figure 4. (15 days) Biomembrane (A): Newly formed bone tissue with large number of osteogenic cells providing continuity to the linear closure process of experimental bone defect (arrows). H/E, 32x. B: Sample with a severe inflammatory condition, characterized by presence of inflammatory infiltrate predominantly composed of polymorphous and mononuclear cells (delimitation). H/E, 32x. C: Scaffold: Increase in the number of osteogenic cells, responsible for formation of more compact mineralized tissue in comparison with the previous time interval (7 days) (arrows). H/E, 32x. D: Inflammatory infiltrate of moderate/intense amplitude (indication) and material residues close to the area of the experimental defect being phagocytized (arrows) H/E, 64x.
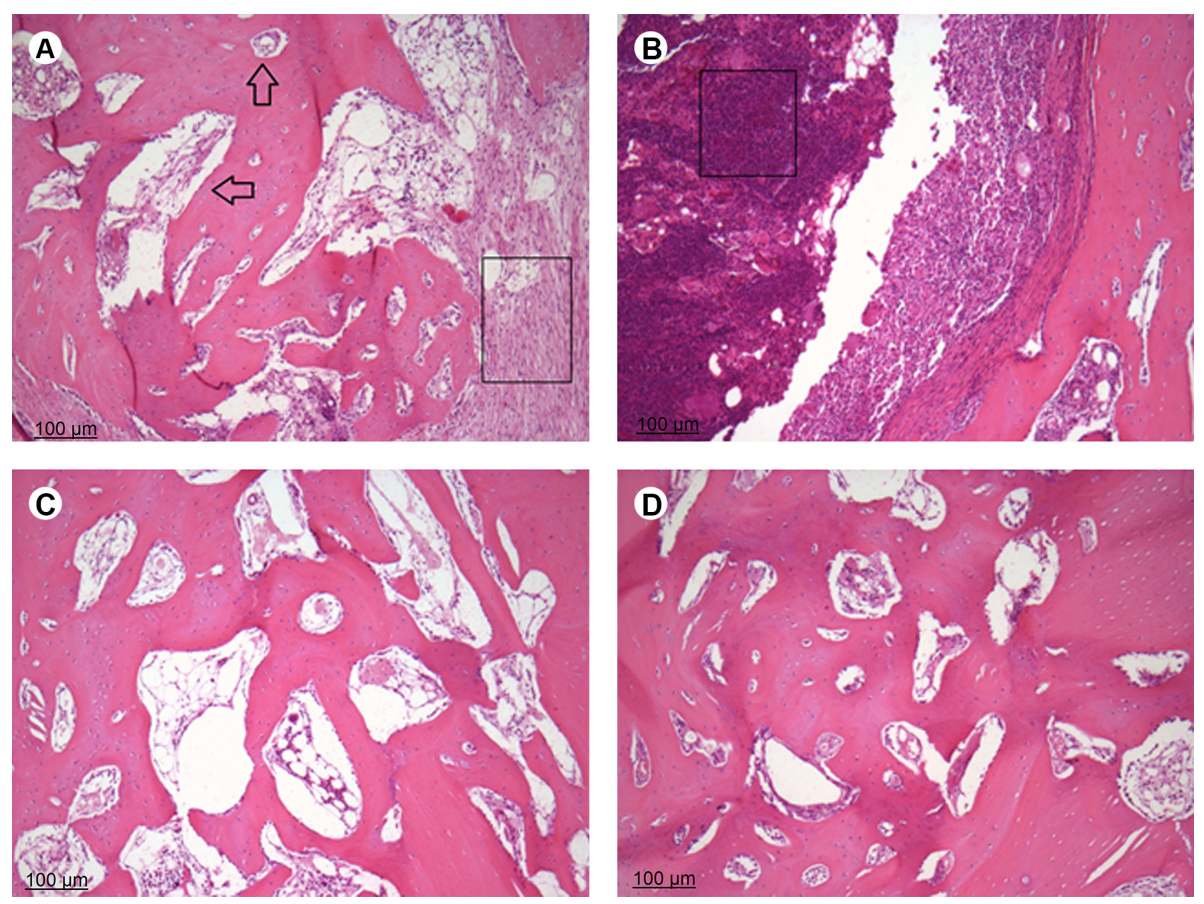

Figure 5. (30 days) A: Biomembrane: inflammatory process of moderate amplitude still persistent (delimitation), without complete linear closure of the experimental defect. Note also the presence of diverse medullary spaces (arrows). H/E, 32x. B: Scaffold: Inflammatory infiltrate of severe amplitude, with foci of necrosis close to the area of the experimental defect (delimitation). H/E, 32x. C: Blood Clot: Inflammatory infiltrate of discrete amplitude observed in the last experimental time interval of analysis, without evident foreign body reaction. H/E, 32x. D: Autologous Bone: As observed in the previous group, there were only a few inflammatory cells at the site. Note the formation of a compact bone structure. H/E, 32x. 
was still observed, without complete linear closure of the experimental bone defect. Diverse medullar spaces could still be noted in the newly formed bone tissue. Necrotic residues were also noted in this time interval. A persistent reaction to the presence of a foreign body could be observed in this period, characterized by the presence of giant cells encircling residues of the biomaterial in areas adjacent to the bone defect (Fig. 5A).

\section{Scaffold}

The tissue reaction observed in the different experimental time intervals for this group was generally similar to the reaction observed in the group where the biomembrane was used to fill the bone defect. The presence of an inflammatory infiltrate of moderate amplitude and the characteristics of linear closure of the bone defect between the two experimental groups were also similar. The time interval of 7 days was characterized by formation of new bone tissue, with several young blood vessels along the defect area. Macrophages phagocytizing residues of the scaffold were also detected at this site (Fig. 3b). At 15 days, a more compact mineralized tissue was observed, with a greater number of osteogenic cells in comparison with the previous time interval (Fig. 4c). However, inflammatory infiltrates of moderate amplitude and necrotic residues close to the area of the experimental defect were frequently seen events in this time interval; which persisted until the final time interval of analysis (30 days) (Fig. 4d). Moreover, in this last time interval of analysis, the occurrence of continuous formation of a thick cortical bone tissue was observed, with fewer medullar spaces in comparison with the previous time intervals and morphological characteristics similar to the bone close to the experimental defect (Fig. 5b).

\section{Blood Clot (Negative Control)}

The tissue reaction observed for this group at 7 days was characterized by the presence of a discrete inflammatory infiltrate and formation of a tissue with thinner bone trabeculae (Fig. 3c). At 15- and 30-day-periods, the formation of a new bone tissue presented evolution similar to the one observed in the group where the biomembrane was used for bone defect filling. A larger quantity of bone trabeculae with lamellar arrangement was also noted in these two periods of analysis. The inflammatory infiltrate remained discrete during the course of the experimental times and practically no foreign body reaction was observed along the period of analysis (Fig. 5c).

\section{Autologous Bone (Positive Control)}

As the experimental defect in this group was filled with autologous bone, over the course of the time intervals of analysis, linear closure could be observed in the space between the grafted bone and defect margin, with the formation of a more irregular mineralized tissue, however, with a morphology similar to the adjacent bone tissue. In the initial time interval of analysis (7 days), there was an inflammatory infiltrate of moderate amplitude, with predominance of polymorphous and mononuclear cells (Fig. $3 d$ ). However, along the time intervals ( 15 and 30 days), significant reduction was observed in the amplitude of the inflammatory infiltrate, with no foreign body reaction in the site of the bone defect (Fig. 5d).

\section{Statistical Analysis \\ Inflammation}

The mean values for the rate of inflammation and their statistical comparison are in Table 3.

There was no significant difference when the experimental time intervals (7, 15 and 30 days) were compared, irrespective of the analyzed group ( $p>0.05)$. The biomembrane group presented greater inflammatory response at 15 days, with significant difference to the group in which the autologous bone was grafted $(p<0.05)$. In the other time intervals, there were no significant differences among groups ( $p>0.05)$.

\section{New bone formation}

The mean values for the new bone formation and their statistical comparison are in Table 4.

Only the biomembrane group presented no statistically significant difference among the experimental time intervals $(p>0.05)$. The other groups presented increase in the quantity of newly formed bone tissue after 7 days $(p<0.05)$. The group subjected to bone graft presented significantly higher values at 30 days in comparison with the biomembrane and negative control (blood clot) groups $(p<0.05)$. The values of autologous bone group at 30 day-period were statistically similar to the scaffold group ( $p>0.05$ ).

\section{Foreign Body Reaction}

The mean values for the foreign body reaction and their statistical comparison are in Table 5.

There was no statistically significant difference when the experimental time intervals were compared ( $p>0.05)$. In the same way, when the groups were compared among them, there was also no statistically significant difference ( $p>0.05$ ).

\section{Discussion}

According to the results obtained from this research, the authors affirm that the tested null hypothesis was partially accepted, since the evaluated biomaterials presented similar biocompatibility at the 30 day-period of analysis, 
compared with each other and the control groups. However, the biomembrane group presented in the last period lower values for newly formed bone tissue, compared with the group subjected to bone graft.

In this study, the authors observed presence of an inflammatory infiltrate of decreasing amplitude during the course of the experimental analysis times In the groups where the biomaterials were implanted, was noted an inflammatory infiltrate of moderate amplitude, close to severe, particularly in the time interval of 15 days. In the control groups (positive and negative), this infiltrate remained discrete in all the time intervals of analysis, probably due to the initial surgical trauma and the important participation of inflammatory cells in the local repair process that occurred with time. This tissue response observed in the control groups was expected, due to the nature of the materials used for filling the defects (blood clot and autologous bone).

As the tested biomaterials were basically composed by three different components, the sum of their effects provided some of the results obtained in the present study. Garcia et al. (20) evaluating the local biocompatibility of calcium aluminate cement, observed an inflammatory response in the subcutaneous tissue of rats with a pattern similar to the one obtained in the present study. This was also observed when the calcium aluminate cement was used for filling bone defects, with continuous reduction in the amplitude of the inflammatory infiltrate and linear closure of the experimental defects along the times of analysis (12).

Saghiri et al. (19) reported that inflammatory infiltrate tended to diminish with the course of time, and the higher the medium $\mathrm{pH}_{\text {, }}$ the more evident would be the inflammatory response. With time, the calcium aluminate tended to stabilize the medium $\mathrm{pH}$, turning it alkaline due to the release of $\mathrm{Ca}^{2+}$ ions (13), which produced a favorable environment for tissue repair $(13,20)$. This may have been crucial for the inflammatory response over the course of the experimental time intervals, and for the pattern of tissue repair observed in the groups submitted to implantation of the biomaterials and the negative control group (blood clot), which resulted in significant difference in the final period of analysis.

There were also noted macrophages phagocyting small fragments of the tested biomaterials , showing an inflammatory response of greater intensity (moderate) in the treated groups in comparison with the control groups, particularly in the initial time interval. However, it is worth pointing out that in a recent study in which collagenbased scaffolds and chitosan were 
submitted to a culture of macrophages in vitro, there were no cytotoxic or adverse effects caused by these components on the macrophages (21). These data suggest that the greater presence of inflammatory cells (macrophages) observed in the groups where the bone defects were filled with the experimental biomaterials, occurred as a resorption phase of the nontoxic product. As observed in this study, the biomaterials were progressively replaced by a new bone tissue with characteristics of normality, over the course of time.

Concerning new bone formation, in all the evaluated groups, in the initial time interval of seven days, there was formation of immature bone tissue and local neovascularization. The great advantage of this new class of biomaterials is their capacity for stimulating early vascular invasion (20). Thus, in the other time intervals (15 and 30 days) there was formation of a bone tissue with the tendency to linear closure of the defect. Comparing the different groups with each other, the authors observed that in the group with the autologous bone (positive control), there was formation of a new tissue with morphological characteristics similar to the bone adjacent to the area of the experimental defect. This type of graft is considered ¿ the "gold standard" due to its origin. However, in spite of the patient being the best biological source for obtaining this material, its collection may frequently be limited (22).

Only in the group in which the biomembrane was implanted, there was no significant difference in the time intervals of observation (7, 15 and 30 days). In spite of having a composition similar to the biomembrane, the scaffold group did not present this pattern, and there was a significant increase in the formation of new bone tissue starting from the initial time interval of analysis. Calcium aluminate causes intense $\mathrm{Ca}$ ion release in the implanted medium, stimulating the differentiation and migration of bone cells (12). In addition, as the scaffold had a three-dimensional structure, greater porosity and quantity of calcium aluminate in its mineral phase, in comparison with the biomembrane, osteoprogenitor cells were able to interlace with the biomaterial, triggering intense fibroangioblastic proliferation, accelerating the process of bone repair and neoformation $(11,12)$.

In spite of the known biocompatibility of collagen and chitosan, some events suggestive of foreign body type reaction occurred in the present study. Nevertheless, the presence or absence of giant cells among the groups was not statistically significant. Chronic inflammation has also been used for describing the foreign body reaction in which monocytes, macrophages and giant cells are present at the biomaterial/host interface (22). The persistence of the inflammatory response beyond three weeks generally indicated infection (22), a fact not observed in this research.
Based on the results obtained in the present study, it was possible to state that the tested biomembrane and scaffold presented behavior similar to control groups in the 30-day analysis with respect to biocompatibility. Considering the osteoinductive capacity of both biomaterials, the biomembrane group presented in the final period significantly lower values of newly formed bone tissue compared with the autologous bone group. On the other hand, the scaffold group presented similar results to the group submitted to bone graft, in the final period of analysis. This fact could be explained mainly by the differences observed in the biomaterials' architecture and porosity $(11,20)$. According to the required bone repair to be made, these differences in composition may interfere in a positive or negative manner in the velocity of the tissue new bone formation process $(11,20)$. However, despite these findings, the bioactivity observed in both biomaterials over the course of the experimental time intervals could be considered similar. Such results make the biomembrane and scaffold containing calcium aluminate cement promising adjuvant materials in the treatment of bone defects in different areas of dentistry. Further research involving these biomaterials is required prior to their use in humans.

\section{Resumo}

Biomateriais inovadores podem fornecer uma promissora nova direção para o tratamento de defeitos ósseos, estimulando um processo de reparo adequado, sem danos aos tecidos adjacentes. 0 objetivo deste estudo in vivo foi avaliar a biocompatibilidade e a capacidade osteoindutora de uma biomembrana e um scaffold compostos por colágeno e quitosana, contendo cimento de aluminato de cálcio. Dezoito coelhos (New Zealand White, Oryctolagus cuniculus) foram distribuidos de acordo com os periodos experimentais de análise (7, 15 e 30 dias). Quatro defeitos foram criados na calvaria dos coelhos, que foram individualmente preenchidos com a biomembrana, scaffold, coágulo (controle negativo) e osso autólogo (controle positivo). A avaliação histopatológica foi realizada em microscópio óptico em aumentos de $32 \times, 64 \times, 125 \times$ e $320 \times$. A resposta celular à inflamação e à formação de novo tecido ósseo foi quantificada utilizando um sistema de escore. 0 grupo da biomembrana apresentou maior resposta inflamatória no periodo de 15 dias, com diferença significativa para o grupo do osso autólogo $(p<0,05)$. Não houve diferença estatística significante para a reação do tipo corpo estranho entre os grupos $(p>0,05)$. Em relação à neoformação óssea, observou-se fechamento linear da área do defeito, que foi mais evidente no grupo em que se utilizou o osso autólogo. 0 grupo scaffold apresentou resultados semelhantes ao grupo do osso autólogo no período de 30 dias $(p>0,05)$. Ambos os biomateriais testados apresentaram biocompatibilidade similar em comparação com os grupos controle. Além disso, a biomembrana e o scaffold apresentaram capacidade osteoindutora similar, estimulando o reparo ósseo ao longo dos intervalos de tempo experimentais.

\section{Acknowledgements}

The authors would like to thank the "National Council for Scientific and Technological Development - CNPq" (Grants \#303599/2014-6; \#443153/2014-0 and \#67/2008 - RHAE) for the financial support.

\section{References}

1. Nakamura A, Akahane M, Shigematsu H, Tadokoro M, Morita Y, Ohgushi 
$\mathrm{H}$, et al.. Cell sheet transplantation of cultured mesenchymal stem cells enhances bone formation in a rat nonunion model. Bone 2010;46:418424.

2. Canter $\mathrm{HI}$, Vargel I, Mavili ME. Reconstruction of mandibular defects using autografts combined with demineralized bone matrix and cancellous allograft. J Craniofac Surg 2007;18:95-100.

3. Li $Y$, Fang $X$, Jiang $T$. Minimally traumatic alveolar ridge augmentation with a tunnel injectable thermo-sensitive alginate scaffold. J Appl Oral Sci 2015;23:215-223.

4. Takechi M, Ohta $K$, Ninomiya $Y$, Tada M, Minami M, Takamoto M, et al.. 3-dimensional composite scaffolds consisting of apatite-PLGAatelocollagen for bone tissue engineering. Dent Mater J 2012;31:465471.

5. Tuan TL, Keller LC, Sun D, Nimni ME, Cheung D. Dermal fibroblasts activate keratinocyte outgrowth on collagen gels. J. Cell Sci 1994;107:2285-2289.

6. Ma L, Gao C, Mao Z, Zhou J, Shen J, Hu X, et al.. Collagen/chitosan porous scaffolds with improved biostability for skin tissue engineering. Biomaterials 2003;24:4833-4841.

7. Kim EC, Lee BC, Chang HS, Lee W, Hong CU, Min KS. Evaluation of the radiopacity and cytotoxicity of Portland cements containing bismuth oxide. Oral Surg Oral Med Oral Pathol Oral Radiol Endod 2008;105:e54-e57.

8. Zheng Z, Wei Y, Wang G, Gong Y, Zhang X. Surface characterization and cytocompatibility of three chitosan/polycation composite membranes for guided bone regeneration. J Biomater Appl 2009;24:209-229.

9. Liu $\mathrm{H}$, Peng $\mathrm{H}, \mathrm{Wu} \mathrm{Y}$, Zhang $\mathrm{C}$, Cai $\mathrm{Y}, \mathrm{Xu} \mathrm{G}$, et al.. The promotion of bone regeneration by nanofibrous hydroxyapatite/chitosan scaffolds by effects on integrin-BMP/Smad signaling pathway in BMSCs. Biomaterials 2013;34:4404-4417.

10. Martino A, Sittingerc M, Risbuda MV. Chitosan: A versatile biopolymer for orthopaedic tissue-engineering. Biomaterials 2005;26:5983-5990.

11. Soares DG, Rosseto HL, Basso FG, Scheffel DS, Hebling J, Costa CA. Chitosan-collagen biomembrane embedded with calcium-aluminate enhances dentinogenic potential of pulp cells. Braz Oral Res 2016;30:e54.

12. Garcia L da F, Huck C, Scardueli CR, de Souza Costa CA. Repair of bone defects filled with new calcium aluminate cement (Endobinder). J Endod 2015;41:864-870.

13. Kanaya $S$, Nemoto E, Ebe $Y$, Somerman MJ, Shimauchi H. Elevated extracellular calcium increases fibroblast growth factor-2 gene and protein expression levels via a cAMP/PKA dependent pathway in cementoblasts. Bone 2010;47:564-572.

14. Demirkaya K, Can Demirdöğen B, Öncel Torun Z, Erdem O, Çetinkaya S, Akay C. In vivo evaluation of the effects of hydraulic calcium silicate dental cements on plasma and liver aluminium levels in rats. Eur J Oral Sci 2016;124:75-81.

15. Silva EJ, Herrera DR, Rosa TP, Duque TM, Jacinto RC, Gomes BP, et al.. Evaluation of cytotoxicity, antimicrobial activity and physicochemical properties of a calcium aluminate-based endodontic material. J Appl Oral Sci 2014;22:61-67.

16. Noetzel J, Ozer K, Reisshauer BH, Anil A, Rössler R, Neumann K, et al.. Tissue responses to an experimental calcium phosphate cement and mineral trioxide aggregate as materials for furcation perforation repair: a histological study in dogs. Clin Oral Investig 2006;10:77-83.

17. Panzarini SR, Holland R, De Souza V, Poi WR, Sonoda CK, Pedrini D. Mineral trioxide aggregate as a root canal filling material in reimplanted teeth. Microscopic analysis in monkeys. Dent Traumatol 2007;23:265-272.

18. Moretton TR, Brown CE, Legan JJ, Kafrawy A. Tissue reactions after subcutaneous and intraosseous implantation of mineral trioxide aggregate and ethoxybenzoic acid cement. J Biomed Mater Res 2000;52:528-533.

19. Saghiri MA, Orangi J, Tanideh N, Asatourian A, Janghorban K, Garcia-

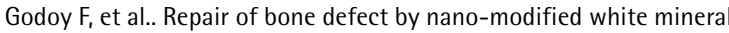
trioxide aggregates in rabbit: A histopathological study. Med Oral Patol Oral Cir Bucal 2015;20:e525-e531.

20. Garcia L da F, Huck $C$, Menezes de Oliveira L, de Souza PP, de Souza Costa CA. Biocompatibility of new calcium aluminate cement: tissue reaction and expression of inflammatory mediators and cytokines. $J$ Endod 2014:40:2024-2029.

21. Mahmoudzadeh A, Mohsenifar A, Rahmani-Cherati T. Collagenchitosan 3-D nano-scaffolds effects on macrophage phagocytosis and pro-inflammatory cytokine release. J Immunotoxicol 2016;4:1-9.

22. Intini G, Andreana $S$, Buhite RJ, Bobek LA. A comparative analysis of bone formation induced by human demineralized freeze-dried bone and enamel matrix derivative in rat calvaria critical-size bone defects. J Periodontol 2008;79:1217-1224.

Received December 12, 2916 Accepted April 3, 2017 